\title{
Suça İlişkin Mekânsal Risk Faktörlerinin Adli Sosyolojik Bakış Açısıyla Analizi 1,2,3
}

\author{
DOI: $10.26466 /$ opus.648796
}

\author{
* \\ Aykut Çalışkan $^{*}$ Tuğça Poyraz ${ }^{*}$ \\ * Dr., Bayburt Emniyet Müdürlüğü, Merkez / Bayburt/ Türkiye \\ E-Posta: aykut629aykut@hotmail.com ORCID: 0000-0002-1886-6991 \\ ** Doç. Dr., Hacettepe Üniversitesi, Edebiyat Fakültesi, Beytepe / Ankara / Türkiye \\ E-Posta: tpoyraz@hacettepe.edu.tr ORCID: 0000-0003-3717-4728
}

\section{$\ddot{O} z$}

Yapılan araştırmalarda suç mekânında bulunan mikro düzey fiziksel tedbirlerin eksikliğinin şiddet suçlarının işlenmesinde anlamlı düzeyde etkisi olduğu sonucuna ulaşılmıştır. Bunun yanı sıra kolektif bilinç, toplumsal denetim ve toplumsal duyarlılık gibi sosyolojik faktörlerin eksikliği de şiddet suçlarının oranını etkilemektedir. Mal varlı̆̆ına karşı suçlar, mala zarar verme, hırsızlık ve yağma suçlarının işlenmesini artıran veya azaltan mekânsal risk faktörlerinin tespit edilmesini amaçlayan bu çalışma, adli sosyolojik bakış açısıyla ele alınmıştır. Nicel araştırma yönteminin kullanıldığı çalışmada malvarlığına karşı suçları işleyen 154 tutuklu ve mahkûma anket formu uygulanmıştır. Anket formuna verilen cevaplar doğrultusunda yapılan sinıflandırma sonucu elde edilen lojistik regresyon analizi sonuçlarına göre; mekânın kamusal alana açık olması suç işlenmesi riskini azaltırken, çeorede insan bulunmaması, hedefin tutuklu ve mahkûm tarafindan müsait ve erişilebilir olarak değerlendirilmesi suçun işlenme riskini arttırmaktadır. Bu noktada mekânda yer alan insan unsuru, hem suçu engelleme özelliği taşımakta hem de suçun oluşması durumunda görgü tanı̆̆ı delilleri vasıtasıyla olayın aydınlatılmasında önem teşkil etmektedir.

Anahtar Kelimeler: Suç, Mekân, Adli Sosyoloji, Rutin Aktiviteler Teorisi, Risk.

\footnotetext{
${ }^{1}$ Bu çalışma, Hacettepe Üniversitesi Fen Bilimleri Enstitüsü Adli Bilimler alanında, 'Adli Sosyoloji Bağlamında Mala Zarar Verme Suçu Ile ilgili Mekân Olgusunun Analizi' başlığı ile yazılan doktora tezinde yer alan analizlerin genişletilmesi sonucu hazırlanmıştır.

${ }^{2}$ Çalışma, Hacettepe Üniversitesi Etik Kurulu tarafindan 22.05.2018 tarihinde verilen karar doğrultusunda hazırlanmıştır.

${ }^{3}$ Çalışmanın yayınlanabilmesi için Ceza ve Tevkifevleri Genel Müdürlüğü'nden 30.07.2019 tarihinde gerekli izin alınmıştır.
} 


\title{
Analysis of Spatial Risk Factors Related To Crime By Forensic Sociological Perspective
}

\begin{abstract}
In the researches, it was concluded that the lack of micro-level physical measures in the crime scene had a significant effect on the committing of violent crimes. In addition, the lack of sociological factors such as collective consciousness, social control and social sensitivity affect the rate of violent crimes. This study aims to identify spatial risk factors that increase or decrease the crimes against property, damage to property, theft and loot crimes from a forensic sociological perspective. In this study, a quantitative research method was used and a questionnaire was applied to 154 prisoners and inmates who committed crimes against their assets. According to the results of the logistic regression analysis obtained according to the answers made to the questionnaire; the fact that the space is open to the public sphere reduces the risk of committing a crime, and the absence of people in the environment and the evaluation of the target as appropriate and accessible by the prisoner increases the risk of committing the crime. At this point, the human element in the space has the feature of preventing the crime and in case of the occurrence of the crime, it is important to clarify the incident by means of witness evidence.
\end{abstract}

Keywords: Crime, Place, Forensic Sociology, Routine Activity Theory, Risk. 


\section{Giriş}

Suçun işlendiği mekânların yeterli denetime tabi tutulmayarak başıboş bırakılması, farklı suçlara uygun ortamların oluşmasına sebebiyet verebilmektedir. Bu bağlamda mekân kavramının sadece fiziksel bir olgu olarak değil de suç temelinde anlaşılması, adli sosyolojik bakış açısı kazanmak için önemlidir. Suçun işlendiği olay yeri (suç mekânı), bir yandan mağdurun belirli bir zaman vakit geçirdiği veya ihtiyaçlarını karşılamak amacıyla bir müddet bulunduğu ortamı ifade ederken, mekânın sosyal inşa süreciyle şekillendiğini tespit etmek de diğer bir bakış açısıyla suç probleminin parametrelerini sosyal açıdan kurgulamamız noktasında önem taşımaktadır. Adli bilimler bakış açısı ile olaya dair maddi gerçeğin tespit edilmesinde mekân; bir yönden suçun oluşmasına zemin hazırlayan ortam iken, diğer taraftan bu mekân üzerinde olayın aydınlatılmasına katkı sağlayacak delillerin tespit edilebilmesini sağlayan yer olarak da görülmektedir. Mekânı tasvir eden koşulların belirlenmesi olayın aydınlatılması için bir ön şart olarak kabul edilmektedir.

Yapılan araştırmalarda mekânda bulunan mikro düzey fiziksel tedbirlerin eksikliği ile kolektif bilinç, toplumsal kontrol ve toplumsal duyarlılık gibi sosyolojik faktörlerin eksikliğinin şiddet suçlarının işlenmesinde anlamlı düzeyde etkisi olduğu sonucuna ulaşılmıştır (Brantingham vd., 1993, s.3-28, Anderson vd., 2012, s.699-756; Groff vd., 2009, s.61-86; Sampson vd., 2004, s.319-342). Bu anlatıdan yola çıkarak toplumsal faktörlerin fiziksel unsurlar ile birlikte mekânı inşa eden değişkenleri oluşturması çalışmanın temel gerekçesidir.

Şiddet suçu işlenen mekâna dair farkındalık oluşturan özeliklerin belirlenebilmesi amacıyla He ve arkadaşları (2017), Amerika'nın Colombus Bölgesi'nde yaptıkları araştırmada birim zamanda gerçekleşen olay sayılarını esas alarak tespit ettikleri bazı fiziksel ve sosyal değişkenler arasında model kurmuşlardır. Modelde yer alan değişkenlere ait değerlerin, yıl içerisinde gerçekleşen olay sayısına ait değerlerinin alınması yoluyla Poisson Dağılımı üzerinden regresyon analizi çalışması yapmışlardır. Kurguladıkları model; 6 faktör altında toplam 11 bağımsız değişken üzerinden temel alınmıştır. Modelde yer alan bağımlı değişken 2002 yılındaki şiddet suçu sayısı olmakla birlikte, 6 faktöre ait sıralanan bağımsız değişkenler ise aşağıdaki gibidir: 
- Sosyo-ekonomik yoksunluk (yoksulluk sinırı altı nüfus yüzdesi, lisans derecesine sahip nüfus yüzdesi, işsiz nüfus oranı),

- Etnik heterojenlik (heterojenlik indeksi, yabancı nüfusun yüzdesi),

- Konut hareketliliği (kirada bulunan konut sayısı, 5 yıl aynı konutta bulunma yüzdesi),

- Aile parçalanması (tek ebeveynli aile yüzdesi),

- Koruyucular (nüfus yoğunluğu-binde, boş konut yüzdesi),

- Motive olmuş suçlu (15-24 yaş arası genç erkek nüfus yüzdesi).

Modelin kurulması ve makro verilerin dâhil edilmesiyle yapılan analiz sonucunda bağımsız değişkenler arasında yer alan; lisans derecesine sahip nüfus yüzdesi, yabancı nüfus yüzdesi ve nüfus yoğunluğu ile şiddet suçu arasında negatif bir ilişki olduğu tespit edilmiştir. Geriye kalan diğer bağımsız değişkenlerin ise pozitif bir ilişkiye sahip olduğu görülmüştür. Diğer taraftan dikkat çeken diğer bir konu, mekâna özgü belirtilen eksiklikleri elverişli değişkenler vasıtasıyla ölçmeye yönelik çalışmaların Türkiye özelinde eksik olmasıdır (Malleson vd., 2012, s.551-561). Bu çalışma, bu eksikliğin giderilmesi kaygısını taşıması açısından önem arz etmektedir.

Mekâna ilişkin maddi gerçeğin ortaya çıarılmasında tercih edilen ve olası sonuçlarıyla maddi bulgular ile yeteri kadar desteklenmediği durumda geçerliliği açısından desteklenmesi gereken delillerden önemli bir tanesi de beyan delilleridir. Beyan delillerinin kendi içerisinde nasıl bir yöntem ile düzenlenmesi gerektiği ve sonrasında yapılacak olan fail araştırmalarında suçun işlendiği mekândan fikir sunan maddi tespitlerden yola çıarak sorunu çözmek adli olaylarda başlıca bir problem ve araştırma alanı olarak görülmelidir. Özellikle malvarlığına karşı işlenen suçların aydınlatılma oranlarının düşük olması, suçu işleyen bireylerin olay yerinde maddi delil bırakmayacak şekilde hareket etmeleri, beyan delillerini işlevsel hale getirmektedir. Beyan delillerinde esas alınması gereken özellikler ise mekânsal risk faktörlerinin belirlenmesi halinde daha anlamlı sonuçların elde edilebilmesine katkı sağlayabilmektedir.

Bu doğrultuda; yaşanan adli olaylarda olayın aydınlatılmasında görgü tanıkları ve mağdurların beyanları olayı şekillendirmekte, olay yerine intikal eden görevli birimlerce ilk veriler bu esasta toplanmakta ve elde edilen beyanlar çerçevesinde olaylar çözümlenmeye çalışılmaktadır. Bu çalışmayla, suçun sacayaklarından biri olarak suç işleyen bireylerin görüşleri dâhilinde suçun çözümüne katkı sağlayan mekânsal risk faktörlerini tespit edil- 
mesi araştırılmakta, aynı zamanda elde edilen bulgular vasitasıyla bu alanda çalışan adli birimlere tavsiye ve öneri niteliğinde bulguların sunulması hedeflenmektedir. Yapılan çalışma adli sosyoloji bakış açısı temel alınarak kurgulanmıştır. Adli makamlar için birincil işlev görevi gören soruşturmaların özel suç temelinde saha çalışmalarıyla pekiştirilmesi, bu alanda görev yapan personel açısından önemlidir.

Yapılan araştırma aynı zamanda mala zarar verme suçu, hırsızlık ve yağma(gasp) suçları arasında elde edilen bulguların karşılaştırılmasına imkân sağlamaktadır. Bu açıklamalar ile birlikte; malvarlığına karşı işlenen suçlar, mala zarar verme, hursızlık ve yağma suçları esas alınarak mekâna dair risk faktörlerinin tespit edilmesi çalışmanın ana problemini oluşturmaktadır.

\section{Adli Sosyoloji}

Adli sosyoloji, mahkemeler tarafından yürütülen ceza veya hukuk davalarında yargılama süreci ve öncesinde savunma ve iddia makamlarının suça ilişkin bulgular elde etme sürecine katkı sağlamaktadır (Petherick, 2010). Adli sosyoloji kapsam olarak; olay yerinin güvenliği çerçevesinde suçun tarafı olan kişilerin ihmali ve yükümlülüklerinin tespiti ile taraflardan elde edilen sosyal süreçlere dair veriler doğrultusunda failin kimliğinin tespit edilmesi aşamalarından oluşmaktadır. Suç mekânındaki ilişki ağları ve bu ilişkiler içerisinde bireyin davranışlarına odaklanılması esas noktasıdır.

Suçtan zarar gören kişiler haricinde olay yerinde bulunan görgü tanıklarının beyanları, hem sonraki süreç için bir delil kaynağı olarak değerlendirilmekte, hem de vermiş oldukları bilgiler sayesinde suçun aydınlatılması sağlanabilmektedir (Forst, 2004). Tanık konumunda yer alan ve olay yerinde bulunan veya sonrasında olayı görmüss olduklarına dair ifade verme maksadıyla sürece dâhil olan kişilerin yanılma olasılıkları, hangi koşullar altında beyanlarını vermiş oldukları olay ile ilgili kurulacak nedenselliğin ve ilintinin oluşturulması adına önem arz etmektedir.

Soruşturmalarda şüphelinin açk kimliğinin tespiti ve temini noktasında mağdur ve müşteki konumda yer alan suçun taraflarının beyanları büyük ölçüde olayı şekillendirmektedir. Bu amaçla olay yerinde toplumsal ve bireysel açıdan ihmal ve kusur boyutlarının tespiti ile çevreye dair mekânsal özelliklerin geniş kapsamda analiz edilmesi soruşturma sürecinde yapılan 
adımlardandır. Adli sosyoloji yaklaşımı, olay bazında suç olarak tanımlanan eylemlerin toplumsal bilince aykırı mahiyette özeliklerinin araştırılması ve adli sürece dâhil olan bireylerin yaşayış biçimleri hususunda veriler sağlaması nedeniyle toplumsal bakış açısı ile yaklaşmanın bir sonucu olarak ortaya çıkmıştır (Füsun, 1997).

Adli sosyoloji alanının suç bilimi alanından ayrılma noktası ise suçu işleyen bireylerin temel alınarak, suçun ortaya çımasına dair değişkenlerin bireylerde nasıl ve neden farklılaştığına dair elde edilen verilerin yanı sıra, bireyler arası ilişkilerde adli olana dair maddi gerçeği tespit etme gayesidir. Bu noktada araştırmada kullanılan yöntemler sosyolojik çalışmalarla metodolojik olarak farklılaşma göstermeyip, adli olaya ilişkin suçu işleyen bireyin bulunduğu sosyal yapının analiz edilmesi ile problemin çözümü mümkün hale gelebilmektedir.

Bu kapsamda adli sosyoloji, bireyin nesne ve özne olarak değerlendirilmesine imkân sağlamaktadır. Suç olgusunu bireyin davranışsal tercihlerinden ayırmadan suç olgusuna neden olan sosyal değişkenler üzerine yoğunlaşmaktadır. Adli sosyoloji suç olayını, yapılan analiz ile bütünleştirerek suçu ve suça dair sosyal süreçleri adli çerçevede açılamaya çalışarak hukuki açıdan işlenme gerekçelerine dair sosyal değişkenler vasıtasıyla veriler sunmaktadır (Ünal, 2007). Bu çerçevede adli sosyoloji alanı ile suçun sosyal bir süreç olduğu kabul edilmekte; özellikle şiddet, töre davaları, namus cinayetleri gibi suçların toplumsal sebeplerinin arka planda değerlendirilmesini gerektiren alanlarda farklı bir bakış açısı ile konuya bütünlük kazandirilmaktadır.

Sosyolojik bakış açısı ile toplumsal düzenin araştırılması ve bu düzen içerisinde aykırı dinamiklerin tespit edilmesi, sosyolojik araştırma yöntemleri kullanılarak yapılmaktadır. Bireylerin davranışlarında genel kalıpların aranması anlamına gelen sosyolojik bakış açısı, "özeldeki geneli görme" anlayışıyla bireysel suç olayından yola çıarak suç olgusunun sosyal nedenlerinin ortaya çıkarılmasını sağlamaktadır (Macions, 2015). Adli olayların sosyolojik bakış açısıyla ele alınması, bireyler için alışılagelenden farklı bir durum ile karşılaşma ve buna tepki verme durumlarını ortaya çıkarması nedeniyle önem teşkil etmektedir. 


\section{Rutin Aktiviteler Teorisi}

Rutin aktiviteler teorisi (RAT), çıkış mantığı olarak dikkatini bireylerin davranışlarının sonuçlarına, davranışın öncesindeki karar mekanizmasındaki olgulara yöneltmektedir. Suç işleyen bireylerin önlerine çıkması muhtemel fırsatları avantaja çevirmesi, kuramın kapsamında yer almaktadır. Klasik Okul yaklaşımının bireyin suçu neden tercih ettiğine dair yaptığı açılamaların yetersiz kalmasıyla, teori kendisini geliştirme alanı bulmuştur (Clarke vd., 2004, s.1-4).

Klasik Okul yaklaşımıla geliştirilen rasyonel tercih kuramı, diğer davranışlar gibi suç teşkil eden davranısların da bireylerin kar-zarar hesabı yapmasiyla kendisini motive eden ve kendisine fayda getiren kararlar sonucunda oluştuğunu ifade etmektedir. Bentham (1979) tarafından faydacılık bakış açısıyla temeli oluşturulan bu yaklaşım sayesinde, insanların davranışsal açıdan fayda getiren eylemleri istemesi ile zarar veren eylemlerden uzaklaşması nedeni ifade edilmiştir. Adı geçen kuramda da suç işleyen bireylerin davranış gerekçesi motive olma kavramıyla ifade edilmiştir (Sherman vd., 1989, s.30-31). Bu teoride bireyin bir davranışı gerçekleştirmeden önce alacağı kararlarda isabetli tercihler yapacağı, bir başka deyişle rasyonel davranacağı kabul edilmektedir. Öte yandan teori, bireyin davranışı tercih etme modelini ifade etse de, davranışa neden olan suç sürecini açıklama konusunda yetersiz kalmıştır.

Rutin aktiviteler teorisi ise bu eksikliği tamamlamak için bireyi suç davranışında rasyonel tercihe iten nedenleri ele almıştır. Bu nedenlerden bir tanesi suçun gerçekleştiği mekândır; birey var olduğu mekânda anlam kazanırken, burada karşılaştığı imkânlar karar alma sürecini etkilemektedir. Cohen ve Felson'un (1979) tarafından bu bakış açısı suçluya odaklanmak yerine, suçun oluştuğu mekânın ve zamanın durumsal belirleyicilerini tespit ederek, suç sürecinin çözümlenmesine katkı sağlama amacı taşımaktadır. Çalışmanın yapılmasında gerekçe olarak artan suç oranlarının etkisinden de bahsedilmiştir.

Bunun yanı sıra şiddet içeren suçların artması ile ilgili 1969 yılında yapılan bir araştırmada bireylerin günlük aktivitelerini evin dışında yoğun bir şekilde gerçekleştirmelerinin suç işleyen bireyler açısından da fırsatları ortaya çıkarabileceği sonucuna ulaşılmıştır. Bu sebeple suça neden olan veya suçlu davranışını anlama noktasında bireyi çevreleyen mekânsal özellikle- 
rin işin içine dâhil edilmesi, rutin aktiviteler teorisinin geliştirilmesine katk1 sağlamıştır. Teori, suçun oluşum aşamaları için birbiriyle ilişkili üç adımı içeren boyutları tanımlamıştır. Bu unsurlar; motive olmuş suçlu, uygun hedef ve koruyucuların yokluğu şeklindedir.

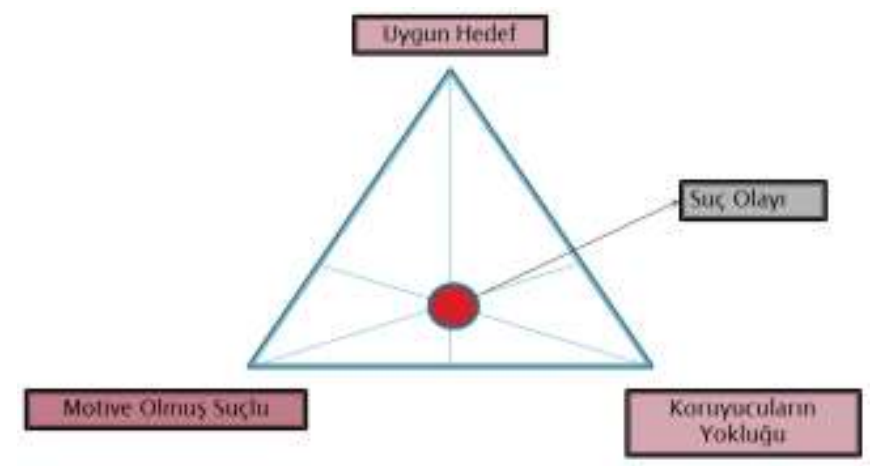

Şekil 1. Rutin Aktiviteler Teorisinde Suçun Oluşum Yapısı

Cohen ve Felson (1979) tarafından geliştirilen bu yaklaşım, belirtilen unsurların bir araya gelmesi durumunda suçun oluşacağını ifade etmektedir. $\mathrm{Bu}$ unsurlardan bir tanesinin eksikliği dahi suçun oluşumunu engelleyecektir. Bu noktada suçun oluşum yapısının anlaşılabilmesi ve aydınlatılmasında belirtilen hususlara dair verilerin toplanması, suçun aydınlatılması aşamasında geçerli veriler üretilmesine katkı sağlayabilecektir. Diğer taraftan anılan unsurların tam anlamıla betimlenmesi, suçun önlenmesi noktasında bizlere bakış açısı kazandıracaktır.

Ayrıca Cohen ve Felson (1979), bireyin suç mağduru olmasına neden olan hedefin; görünür, değerli ve arzu edilebilir, suça korumasız, hareket kabiliyeti ile müsait ve erişilebilir olması durumlarında suç işleyen faillerin ilgisini çekeceğini belirtilmiştir.

Bu mekanizma, suçun oluşum yapısına mekân ve zamanı da ilave ederek suçun oluşumuna farklı algoritmaları dâhil etmesi nedeniyle diğer suç kuramlarından farklılaşmaktadır. Ayrıca farklı zaman ve mekânda suçun oluşum yapısının anlaşılmasıyla suçun denklemi kurularak, bu denklemde yer alan parametreler üzerinden suçu aydınlatma ve çözümleme açısından katkı sağlaması önemlidir. 


\section{Araştırmanın Yöntemi ve Materyali}

Çalışmada anket veri toplama tekniği ve kesitsel bir tarihsel aralık verileri kullanılarak nicel araştırma yöntemi uygulanmıştır. Geliştirilen anket formu için Hacettepe Üniversitesi Etik Kurulundan gerekli izin alınmıştır. Çalışmanın örnekleminde yer alan katılımcı sayısı TÜİK verileri esas alınarak belirlenmiştir. Şöyle ki; TÜİK tarafından mala zarar verme suçundan ceza ve infaz kurumlarına giren hükümlü sayıları yıllar dikkate alınarak açıklanmıştır. Buna bağlı olarak; araştırmadaki örneklem sayısının hesaplanmasında güncel verilerin kullanılmasına özen gösterilerek 2013-2016 yılları arasında mala zarar verme suçundan hüküm alan birey sayıları kullanılmıştır (tuik.gov.tr, Erişim Tarihi: 7 Mart 2018).

Tablo 1. Yillara ve Cinsiyete Göre Türkiye Geneli Mala Zarar Verme Suçunun Hükümlü Sayıları

\begin{tabular}{llll}
\hline Yıllar & Erkek Hükümlü & Kadın Hükümlü & Toplam \\
\hline $\mathbf{2 0 1 3}$ & 3.370 & 153 & 3.523 \\
$\mathbf{2 0 1 4}$ & 2.369 & 81 & 2.450 \\
$\mathbf{2 0 1 5}$ & 2.224 & 84 & 2.308 \\
$\mathbf{2 0 1 6}$ & 2.340 & 88 & 2.428 \\
Ortalama & 2.576 & 102 & 2.677 \\
\hline
\end{tabular}

TÜİK verilerinden hükümlü sayılarına göre mala zarar verme suçundan 2013-2016 yıl aralığında ortalama 2.677 hükümlünün ceza ve tevkif evlerinde olduğu anlaşılmıştır. Çalışmamızın evrenini; Ceza İnfaz Kurumu'nda bulunan ve malvarlığına karşı suç işleyen bireyler oluşturmuştur. 2013-2016 yıllarını yansıtan ve mala zarar verme suçundan hüküm giymiş ortalama 2.677 kişi bulunmaktadır. Kitleyi temsil edebilecek birey sayısinı;

- Örneklem hata payı 0,05 olarak tespit edilerek,

- Malvarlığına karşı işlenen suçların diğer suçların yaklaşık olarak güncel veri olan 2016 y1lı istatistiklerine göre ortalama binde 12 'sini oluşturduğu hesaplandığında; örneklem sayısı 60 erkek, 5 kadın olmak üzere toplam 65 birey olarak belirlenmiştir.

Hüküm giymiş bireylerden mekân olgusu özelinde sosyolojik faktörlerin analizi sürecinde illerin mevcut örneklemde en iyi şekilde temsil edilebilmesi ve mevcut durumunun sosyal ve demografik değişkenlere ilişkin farklı- 
lıkları öngörebilecek şekilde tasarlanabilesi için en çok suçun işlendiği iller tercih edilmiştir. Örnekleme katılacak olan bireylerin erkek ve kadın mahkûmlardan oluşması, yaş dağılımı olarak 18 ile 65 yaş arasında dağılması amaçlanmıştır. Bu amaçla; yapılan çalışma belirtilen koşulların sağlanabilmesi için mala zarar verme suçu özelinde suçun işlenme sayısı en fazla olan 3 il (İstanbul, Ankara ve İzmir) üzerinden gerçekleştirilmiştir.

Çalışmada anket formlarında yaşanabilecek veri kaybı dikkate alınarak hesaplanan örneklem sayısının (65 kişi) iki katı olmak üzere; 120 erkek, 10 kadın (İstanbul için 50 erkek, 5 kadın; İzmir için 45 erkek, 3 kadın ve Ankara ili için 25 erkek, 2 kadın) toplam 130 kişiye uygulanması amaçlanmıştır. Ceza ve infaz kurumlarında gönüllülük esasına göre daha fazla katılım sağlanmış, 154 tutuklu veya mahkûmun katılımıyla çalışma gerçekleştirilmiştir.

Tablo 2. Anketin Yapıldığı İllerden Katılan Katılımcılara İlişkin Frekans Tablosu

\begin{tabular}{llll}
\hline S.No & Iller & Frekans & Yüzde \\
\hline $\mathbf{1}$ & İstanbul & 69 & 44,8 \\
$\mathbf{2}$ & İzmir & 45 & 29,2 \\
$\mathbf{3}$ & Ankara & 40 & 26 \\
& Toplam & 154 & 100 \\
\hline
\end{tabular}

Anket çalışmasına İstanbul İlinden 69, İzmir İlinden 45, Ankara ilinden 40 tutuklu ve mahkûm olmak üzere toplamda 154 kişi katılmıştır. TÜiK verileri göz önünde bulundurularak planlanan örneklem sayısından daha fazla sayıda katılımcılının anket çalışmasına gönüllülük esasına göre katılımi sağlanmıştır.

Tablo 3.Örneklemin Cinsiyetlerine İlişkin Frekans Tablosu

\begin{tabular}{llll}
\hline S.No & Cinsiyet & Frekans & Yüzde \\
\hline $\mathbf{1}$ & Kadın & 16 & 10,4 \\
$\mathbf{2}$ & Erkek & 138 & 89,6 \\
Toplam & & 154 & 100 \\
\hline
\end{tabular}

Örneklemi oluşturan tutuklu ve mahkûmlardan 16'sı kadınlardan, 138'i ise erkeklerden oluşmaktadır. Çalışmaya katılan kadınlar Ankara Kadın Kapalı Ceza ve İnfaz Kurumu'ndan katılmışlardır. Çalışmaya katılan erkek katılımcılar ise örneklem kapsamında yer alan İstanbul, İzmir ve Ankara ceza infaz kurumlarından katılmışlardır. 
Tablo 4. Örneklemin Yaşlarına İlişkin Betimleyici İstatistikler

\begin{tabular}{ccccc}
\hline Örneklem Sayısı & Minimum Değer & Maksimum Değer & Ortalama & Standart Sapma \\
\hline 131 & 18 & 53 & 31,11 & 7,414 \\
\hline
\end{tabular}

Tutuklu ve mahkûmların 131 tanesi yaş değişkenine dair soruya cevap vermişlerdir. Yaşa ilişkin değerler incelendiğinde; en düşük yaş değerinin 18 olduğu, en yüksek yaş değerinin ise 53 olduğu görülmektedir. Ortalama yaşın yaklaşık olarak 31 olduğu ve standart sapmanın 7,4 olduğu tespit edilmiştir. Ayrıca betimleyici istatistik sonucunda elde edilen standart sapma değerinden faydalanarak yaşa ilişkin değerler aşağıda belirtilen frekans tablosunda da gösterilerek yaş dağılımları hakkında fikir verilmiştir.

Tablo 5. Örneklemin Yaşlarına İlişkin Frekans Tablosu

\begin{tabular}{clcc}
\hline S.No & Yaş Aralı̆̆1 & Frekans & Yüzde \\
\hline $\mathbf{1}$ & 18-25 Yaş Arası & 31 & 20,1 \\
$\mathbf{2}$ & 26-31 Yaş Arası & 43 & 27,9 \\
$\mathbf{3}$ & 32-39 Yaş Arası & 35 & 22,7 \\
$\mathbf{4}$ & 40-53 Yaş Arası & 22 & 14,3 \\
$\mathbf{5}$ & Kayıp Veri & 23 & 14,9 \\
& Toplam & 154 & 100 \\
\hline
\end{tabular}

18 ve 53 yaş arasında yer alan tutuklu ve mahkûmların 4 grupta kategorize edilmesi uygun görülmüş ve yaş aralıklarında yer alan katılımcı sayıları belirtilmiştir. Çalışmaya katılan 23 katılımcı yaşa ilişkin herhangi bir veri girmemiştir. Frekans tablosu incelendiğinde en yüksek dağılımın \%27,9 ile 26-31 yaş aralığında olduğu görülmektedir. Diğer yaş dağılımlarının 40-53 yaş aralığı haricinde $(\% 14,9)$ benzer bir oran gösterdiği anlaşılmaktadır. Bu bağlamda malvarlığına karşı işlenen suçlar bağlamında örneklemin \%48'inin 31 yaş altı olduğu görülmektedir.

Tablo 6. Örneklemin Ĕ̆itim Durumlarına İlişkin Frekans Tablosu

\begin{tabular}{rlcc}
\hline S.No & Eğitim Durumu & Frekans & Yüzde \\
\hline $\mathbf{1}$ & Okuma Yazma Bilmiyor & 15 & 9,7 \\
$\mathbf{2}$ & Okuma Yazma Biliyor & 10 & 6,5 \\
$\mathbf{3}$ & İlkokul & 33 & 21,4 \\
$\mathbf{4}$ & Ortaokul & 46 & 29,9 \\
$\mathbf{5}$ & Lise & 38 & 24,7 \\
$\mathbf{6}$ & Yüksek Okul/Üniversite & 12 & 7,8 \\
& Toplam & 154 & 100 \\
\hline
\end{tabular}


Çalışmaya katılan 154 kişiden yaklaşık olarak \%10'una denk gelen 15 kişinin okuma yazma bilmediği, 10 kişinin ise sadece okuma ve yazma bildiği anlaşılmıştır. 33 katılımanın ilkokul mezunu olduğu, 46 kişinin ortaokul mezunu olduğu ve tüm oransal dilim içerisinde ortaokul ve altında eğitim durumuna sahip olan bireylerin $\% 67,5^{\prime}$ lik bir orana sahip olduğu görülmüştür. Ayrıca lise mezunu 38 kişi, yüksekokul mezunu ise sadece 12 kişi bulunmaktadır.

Eğitim durumunun önemli oranda lise altında olduğu görülmüştür. Suç davranışına yönelen bireylerin yeterli düzeyde eğitim faaliyetlerine yönelmedikleri anlaşılmıştır. Temel eğitimin 12 yll olduğu ülkemiz eğitim sisteminde çalışmaya konu örneklemde yer alan bireylerin ortaokul ve altı eğitim durumuna sahip frekans yüzdesinin \%67,5 olarak bulunması kayda değer bir bulgudur.

Çalışma kapsamında risk değişkenlerini tespit etmek ve risk değerlerinin belirlenebilmesi için araştırmaya katılan tutuklu ve mahkûmların işlemiş olduğunu belirttiği malvarlığına karşı suçlar arasında yer alan mala zarar verme, hırsızlık ve yağma suçlarının bağımlı değişken olarak tespit edilmesi, aynı zamanda ikili değer almaları (1;Evet, 0;Hayır) ve dikotom değişken özelliği taşımaları sebebiyle lojistik regresyon analizi kullanılmıştır.

Lojistik regresyon modelinde bu kısımda kullanılan bağımsız değişkenler ve bağımlı değişkenler üzerindeki etkilerinin ölçülebilmesi için lojistik regresyon modeli uygunluk testi ve yapilan regresyon analizi sonrasında etki eden değişkenler ve risk katsayıları belirlenmeye çalışılmıştır.

Çalışmanın analizleri IBM SPSS Statistics 23 paket programında yapılmıştır. Paket programının analiz için sunmuş olduğu model için ayrı ayrı analizler yapılarak sonuçlar incelenmiş, model dâhilinde yapılan atamalarda en verimli sınıflandırmanın yapıldığı modelin varsayım ve sonuçlarına yer verilmiştir. Analiz sonuçları ifade edilmeden önce bağımlı ve bağımsız değişken olarak ifade edilen değişkenler sırasıyla paylaşılmıştır.

Tablo 7. Bă̆ımlı Değişkenlerin Sınıflandırılması

\begin{tabular}{lll}
\hline \multirow{3}{*}{ Bağımlı Değişken } & \multicolumn{1}{c}{$\mathrm{C} 1$} & Mala Zarar Verme \\
\cline { 2 - 3 } & $\mathrm{C} 2$ & Hırsızlık \\
\cline { 2 - 3 } & $\mathrm{C} 7$ & Yağma(Gasp) \\
\hline
\end{tabular}

Yapılan araştırmada tutuklu ve mahkûmların işlemiş olduğu suçlar kısmında yer alan 5237 sayılı Türk Ceza Kanunu'na göre malvarlığına karşı işlenen suçlar içerisinde bulunan ve çalışmada dikotom değişken özelliği göste- 
ren (0;Hayır,1;Evet) mala zarar verme, hırsızlık ve yağma (gasp) suçları çerçevesinde analiz yapılacaktır.

Tablo 8. Bağımsız Değişkenlerin Sınıflandırılması

\begin{tabular}{|c|c|c|c|}
\hline \multirow{5}{*}{ D1 } & \multirow{5}{*}{ Zarar Verilen Mekân } & D1(1) & Mağdurun Evi \\
\hline & & $\mathrm{D} 1(2)$ & Mağdurun İşyeri \\
\hline & & $\mathrm{D} 1(3)$ & Kamu Kurumu \\
\hline & & $\mathrm{D} 1(4)$ & $\begin{array}{l}\text { Kamuya Açk Alan (Park, Cadde } \\
\text { gibi alanlar) }\end{array}$ \\
\hline & & $\mathrm{D} 1(5)$ & $\begin{array}{l}\text { Trafikte Park Halinde/Seyreden } \\
\text { Araç }\end{array}$ \\
\hline \multirow{5}{*}{ D2 } & \multirow{5}{*}{ Mağdur İle Yakınlık Derecesi } & D2(1) & Akrabam \\
\hline & & $\mathrm{D} 2(2)$ & Eşim \\
\hline & & $\mathrm{D} 2(3)$ & Arkadaşım \\
\hline & & D2(4) & Komşum \\
\hline & & D2(5) & Tanımiyorum \\
\hline \multirow{4}{*}{ D3 } & \multirow{4}{*}{ Zarar Verilen Saat Dilimi } & D3(1) & Gece 24-Sabah 6 \\
\hline & & D3(2) & Sabah 6-Öğle 12 \\
\hline & & $\mathrm{D} 3(3)$ & Öğle 12-Akşam 18 \\
\hline & & D3(4) & Akşam 18-Gece 24 \\
\hline D9_1 & Fiziksel ve Çevresel Tedbir (Kamera) & D9_1 & Evet \\
\hline D9_2 & $\begin{array}{l}\text { Fiziksel ve Çevresel Tedbir (Çevre Duvarı veya } \\
\text { Çiti) }\end{array}$ & D9_2 & Evet \\
\hline D9_3 & Fiziksel ve Çevresel Tedbir (Polis/Jandarma) & D9_3 & Evet \\
\hline D9_4 & Fiziksel ve Çevresel Tedbir(Koruma Demirleri) & D9_4 & Evet \\
\hline D9_5 & Fiziksel ve Çevresel Tedbir (İnsan) & D9_5 & Evet \\
\hline D9_6 & Fiziksel ve Çevresel Tedbir (Hayvan) & D9_6 & Evet \\
\hline D9_7 & $\begin{array}{l}\text { Fiziksel ve Çevresel Tedbir (Aydınlatma Siste- } \\
\text { mi) }\end{array}$ & D9_7 & Evet \\
\hline D10_1 & Zarar Verilen Malın Görünür Olması & D10_1 & Evet \\
\hline D10_2 & Değerli ve Arzu Edilir Olması & D10_2 & Evet \\
\hline D10_3 & Suça Karşı Korumasız Olması & D10_3 & Evet \\
\hline D10_4 & Hareket Kabiliyetinin Kolay Olması & D10_4 & Evet \\
\hline D10_5 & Hedefin Müsait ve Erişilebilir Olması & D10_5 & Evet \\
\hline
\end{tabular}

Yapılan araştırmada; çalışma kapsamında katılımcılara yönlendirilerek modelde yer verilen bağımsız değişkenler yukarıda sınıflandırılmıştır. Bağımsız değişkenler binary lojistik regresyon modeline uygun olarak nominal değişken özelliği göstermesi nedeniyle çalışma kapsamında minör faktörlerin etkilerinin belirlenebilmesi için yapay kodlama yapılarak çalışmada kullanılan programa tanıtılmış, ve parametre kodları anlaşılır olması için aşağıda frekans tablosu ile birlikte paylaşılmıştır. Bu çalışma aynı zamanda temel 
değişken olarak belirlediğimiz majör değişkenlerimizin alt etki alanlarını tespit edilmesini planladığından dolayı farkındalık oluşturmaktadır.

Tablo 9. Bă̆ımsız Değişkenlerin Yapay Kodlamalan(Mala Zarar Verme, Hırsızlık ve Gasp Suçu)

\begin{tabular}{|c|c|c|c|c|c|c|}
\hline \multirow[t]{2}{*}{ Majör Değişkenler } & \multirow[t]{2}{*}{ Minör Değişkenler } & \multirow[t]{2}{*}{ Frekans } & \multicolumn{4}{|c|}{ Parametre Kodları } \\
\hline & & & $(1)$ & $(2)$ & (3) & $(4)$ \\
\hline \multirow{5}{*}{$\begin{array}{l}\text { Zarar Verilen Mekân } \\
\text { Kategorik }\end{array}$} & Mağdurun evi & 54 & 1,000 & 0,000 & 0,000 & 0,000 \\
\hline & Mağdurun İşyeri & 53 & 0,000 & 1,000 & 0,000 & 0,000 \\
\hline & Kamu Kurumu & 7 & 0,000 & 0,000 & 1,000 & 0,000 \\
\hline & Kamuya Açık Alan(Park, Cadde, ...) & 17 & 0,000 & 0,000 & 0,000 & 1,000 \\
\hline & $\begin{array}{l}\text { Trafikte Park Halinde/Seyreden } \\
\text { Araç }\end{array}$ & 9 & 0,000 & 0,000 & 0,000 & 0,000 \\
\hline \multirow{5}{*}{$\begin{array}{l}\text { Mağdurla Yakınlık } \\
\text { Derecesi Kategorik }\end{array}$} & Akrabam & 3 & 1,000 & 0,000 & 0,000 & 0,000 \\
\hline & Eşim & 2 & 0,000 & 1,000 & 0,000 & 0,000 \\
\hline & Arkadaşım & 6 & 0,000 & 0,000 & 1,000 & 0,000 \\
\hline & Komşum & 3 & 0,000 & 0,000 & 0,000 & 1,000 \\
\hline & Tanımıyorum & 126 & 0,000 & 0,000 & 0,000 & 0,000 \\
\hline \multirow{4}{*}{$\begin{array}{l}\text { Zarar Verilen Saat } \\
\text { Dilimi Kategorik }\end{array}$} & Gece 24-Sabah 6 & 34 & 1,000 & 0,000 & 0,000 & \\
\hline & Sabah 6-Öğle 12 & 23 & 0,000 & 1,000 & 0,000 & \\
\hline & Öğle 12- Akşam 18 & 53 & 0,000 & 0,000 & 1,000 & \\
\hline & Akşam 18-Gece 24 & 30 & 0,000 & 0,000 & 0,000 & \\
\hline \multirow{2}{*}{$\begin{array}{l}\text { Fiziksel ve Çevresel } \\
\text { Tedbir (Kamera) }\end{array}$} & Hayır & 61 & 1,000 & & & \\
\hline & Evet & 79 & 0,000 & & & \\
\hline \multirow{2}{*}{$\begin{array}{l}\text { Fiziksel ve Çevresel } \\
\text { Tedbir (Çevre Duvarı veya } \\
\text { Çiti) }\end{array}$} & Hayır & 111 & 1,000 & & & \\
\hline & Evet & 29 & 0,000 & & & \\
\hline \multirow{2}{*}{$\begin{array}{l}\text { Fiziksel ve Çevresel } \\
\text { Tedbir (Polis/Jandarma) }\end{array}$} & Hayır & 119 & 1,000 & & & \\
\hline & Evet & 21 & 0,000 & & & \\
\hline \multirow{2}{*}{$\begin{array}{l}\text { Fiziksel ve Çevresel } \\
\text { Tedbir (Koruma Demirleri) }\end{array}$} & Hayır & 107 & 1,000 & & & \\
\hline & Evet & 33 & 0,000 & & & \\
\hline \multirow{2}{*}{$\begin{array}{l}\text { Hedefin Müsait ve } \\
\text { Erişilebilir Olması }\end{array}$} & Hayır & 69 & 1,000 & & & \\
\hline & Evet & 71 & 0,000 & & & \\
\hline \multirow{2}{*}{$\begin{array}{l}\text { Fiziksel ve Çevresel } \\
\text { Tedbir (Hayvan) }\end{array}$} & Hayır & 129 & 1,000 & & & \\
\hline & Evet & 11 & 0,000 & & & \\
\hline \multirow{2}{*}{$\begin{array}{l}\text { Hareket Kabiliyetinin } \\
\text { Kolay Olması }\end{array}$} & Hayır & 116 & 1,000 & & & \\
\hline & Evet & 24 & 0,000 & & & \\
\hline \multirow[t]{2}{*}{ Suça Karşı Korumasız Olması } & Hayır & 102 & 1,000 & & & \\
\hline & Evet & 38 & 0,000 & & & \\
\hline \multirow{2}{*}{$\begin{array}{l}\text { Değerli ve Arzu Edilir } \\
\text { Olması }\end{array}$} & Hayır & 91 & 1,000 & & & \\
\hline & Evet & 49 & 0,000 & & & \\
\hline \multirow{2}{*}{$\begin{array}{l}\text { Zarar Verilen Malın Görünür } \\
\text { Olması }\end{array}$} & Hayır & 78 & 1,000 & & & \\
\hline & Evet & 62 & 0,000 & & & \\
\hline \multirow{2}{*}{$\begin{array}{l}\text { Fiziksel ve Çevresel Tedbir } \\
\text { (Aydınlatma Sistemi) }\end{array}$} & Hayır & 98 & 1,000 & & & \\
\hline & Evet & 42 & 0,000 & & & \\
\hline \multirow{2}{*}{$\begin{array}{l}\begin{array}{l}\text { Fiziksel ve Çevresel Tedbir } \\
\text { (Insan) }\end{array} \\
\end{array}$} & Hayır & 80 & 1,000 & & & \\
\hline & Evet & 60 & 0,000 & & & \\
\hline
\end{tabular}


Mala zarar verilen mekâna dair kattlımclara yöneltilen sorular kapsamında mekânı tasvir eden ve bireye ait taşınır veya taşınmaz malların durumu ile ilgili olduğu değerlendirilen yukarıda belirtilen değişkenlerin önem derecelerin tespit edilmesi amaciyla model içerisinde bahse konu değişkenlere yer verilerek, tutuklu ve mahkûmların tespitleri belirlenmeye çalışılmışıır.

Yapılan analizlerde değişkenlerin yanlarında belirtilen kodların uyarlanmaSı ile elde edilen sonuçlar detaylı bir şekilde açıklanmıştır. Çalışmada majör değişkenlerin etki düzeyleri, yukarıda belirtilen minör değişkenler ile belirlenmeye çalışılmıştır. Bu noktada her bir değişken kategorize edildiği alt başlıklar çerçevesinde model içerisinde yapay değişkemler vasıtasıyla yerleştirilmiştir.

\section{Tablo 10. Hosmer ve Lemeshow Testi Sonuçlan}

\begin{tabular}{lllcccc}
\hline $\begin{array}{l}\text { S. } \\
\text { No }\end{array}$ & Model Türü & $\begin{array}{l}\text { Malvarlı̆̆na Karşı } \\
\text { Suçlar }\end{array}$ & $\begin{array}{c}\text { Ki-Kare } \\
\text { Test } \\
\text { İstatistiği }\end{array}$ & $\begin{array}{c}\text { Serbestlik } \\
\text { Derecesi }\end{array}$ & $\begin{array}{c}\text { Belirleyici } \\
\text { Değer }\end{array}$ & $\begin{array}{c}\text { Negelkerke } \\
\mathbf{R}^{2}\end{array}$ \\
\hline $\mathbf{1}$ & \multirow{2}{*}{ Enter } & Mala Zarar Verme & 3,891 & 8 &, $867^{*}$ & $\mathbf{0 , 3 9 4}$ \\
$\mathbf{2}$ & Modeli & Hırsızlık & 2,669 & 8 &, $953^{*}$ & $\mathbf{0 , 4 9 9}$ \\
$\mathbf{3}$ & Yağma(Gasp) & 10,159 & 8 &, $254^{*}$ & $\mathbf{0 , 3 9 6}$ \\
\hline
\end{tabular}

$\left({ }^{*}\right.$ values $\left.>0,05\right)$

Lojistik regresyon modeline uygunluk testi kapsaminda yapılan Hosmer ve Lemeshow testi sonrasinda IBM SPSS Statistics 23 paket programinin bizlere sunduğu 7 farklı model arasından modelin türü olan enter modeline göre yapılan iterasyon işlemlerinde kurulan model anlamlı bulunmuştur $(p>0,05)$. Yukarıda gösterilen tabloda modeller arasında en verimli sınıflandırmanın yapıldığı enter modeli sonuçları gösterilmiştir. Enter modeli vasıtasıyla tüm bağımsız değişkenlere aynı model içerisinde yer verilerek, bağımlı değişkenin yordanması sağlanmıştır. Ayrıca binary lojistik regresyon modelinin Negelkerke $\mathrm{R}^{2}$ sonuçları dahilinde orta derecede uyumlu olduğu sonucuna ulaşılmiştır [0,394;0,499].

\section{Araştırmanın Bulguları}

Araştırmada suçun işlendiği mekânlar kategorize edilerek, bu mekânlara model içerisinde yer verilmiş, böylelikle mekânının alt değişkenleri minör hale getirilerek anlamlı değişkenler bulunmaya çalışılmıştır. Suç işlemede bireyi teşvik edebileceği değerlendirilen diğer değişkenlerin de model içeri- 
sinde yer alması sağlanarak her bir değişkenin modele ne ölçüde katkı sağladığı tespit edilmeye çalışılmıştır.

\section{Mala Zarar Verme Suçuna Etki Eden Mekânsal Risklerin Belirlenmesi}

Tablo 11. Mala Zarar Verme Suçu Verilerine Lojistik Regresyon Analizi (Enter) Uygulanması Sonucu Değişsenlerin Etki Düzeyleri

\begin{tabular}{|c|c|c|c|c|c|}
\hline Değişkenler & Katsayı & $\begin{array}{l}\text { Wald } \\
\text { İstatistiği }\end{array}$ & $\begin{array}{l}\text { Serbestlik } \\
\text { Derecesi }\end{array}$ & $\begin{array}{l}\text { Belirleyici } \\
\text { Değer }\end{array}$ & Risk Katsayısı \\
\hline D1_1 & & 11,857 & 4 &, $018^{* *}$ & \\
\hline D1_1(1) &,- 426 & ,171 & 1 & 679 & 653 \\
\hline D1_1(2) & $-1,264$ & 1,483 & 1 & ,223 & 282 \\
\hline D1_1(3) & $-1,500$ & 1,175 & 1 & ,278 & 223 \\
\hline D1_1(4) & $-3,111$ & 7,054 & 1 &, $008^{*}$ & ,045 \\
\hline D2_2 & & 6,491 & 4 & , 165 & \\
\hline D2_2(1) & $-1,555$ & 1,135 & 1 & 287 & 211 \\
\hline D2_2(2) & $-2,968$ & 3,037 & 1 & ,081 & 051 \\
\hline D2_2(3) & 2,006 & 2,016 & 1 & ,156 & 7,431 \\
\hline D2_2(4) & 19,797 & ,000 & 1 & ,999 & 395846954,858 \\
\hline D3_3 & & 1,165 & 3 & ,761 & \\
\hline D3_3(1) &,- 101 & ,019 & 1 & 891 & ,904 \\
\hline D3_3(2) &,- 067 &, 006 & 1 & ,937 & ,935 \\
\hline D3_3(3) &,- 589 & ,772 & 1 & 380 & ,555 \\
\hline D9_1(1) &,- 249 & ,248 & 1 & 618 & ,779 \\
\hline D9_2(1) & $-1,668$ & 3,456 & 1 & ,063 & ,189 \\
\hline D9_3(1) & 180 & ,065 & 1 & 798 & 1,197 \\
\hline D9_4(1) &,- 228 & ,101 & 1 & ,751 & ,796 \\
\hline D9_5(1) & 1,204 & 5,130 & 1 &, $024^{*}$ & 3,333 \\
\hline D9_6(1) &,- 103 & ,006 & 1 & ,939 & ,902 \\
\hline D9_7(1) & ,046 & 007 & 1 & ,934 & 1,048 \\
\hline D10_1(1) &,- 341 & ,402 & 1 & ,526 & ,711 \\
\hline D10_2(1) & ,755 & 2,239 & 1 & 135 & 2,127 \\
\hline D10_3(1) & ,003 & ,000 & 1 & ,997 & 1,003 \\
\hline D10_4(1) &,- 032 & ,001 & 1 & ,969 & ,969 \\
\hline D10_5(1) & $-1,203$ & 5,415 & 1 &, $020^{*}$ & ,300 \\
\hline Sabit Değ. & 3,544 & 4,193 & 1 & ,041* & 34,600 \\
\hline
\end{tabular}

$\left({ }^{*} * * 0,05\right), D 1 \_1=$ Zarar Verilen Mekân(Trafikte Park Halinde/Seyreden Araç), D1_1(4)=Zarar Verilen Mekân (Kamuya Açık Alan), D9_5=Insan (Hayır), D10_5=Hedefin Müsait ve Erişilebilir Olmasi(Hayır)

Mala zarar verme suçuna etki edebileceği değerlendirilen ve yukarıda tanımlanan bağımsız değişkenlerin yer aldığı model, IBM SPSS Statistics 23 paket programında lojistik regresyon analizinde kullanıcılara sunulan 3 farklı mo- 
del üzerinden analiz edilmiş, minör değişkenlerin de etkilerinin yer aldığı anlamlı değişkenler sırasıyla paylaşılmıştır ( https://www.ibm.com/ ). Enter modelinde bağımsız değişkenlerin tamamına yer verilerek tek adımda lojistik regresyon analizi gerçekleştirilmektedir

Mala zarar verme suçunu işleyen tutuklu ve mahkûmların görüşleri çerçevesinde \%75,7 oranında doğru yapılan sınıflandırma sonuçlarına göre; mala zarar verilen mekânın "kamuya açı alan" olması durumunda; trafikte park halinde veya seyreden araçlara göre suçun gerçekleşme riski 1,53 kat suçun işlenme riski azalmaktadır. Bu sonuç, suç işleyen bireylerin toplumsal denetime önem verdiklerini göstermektedir. Bireylerin toplu halde bulunabilecekleri yerlerde içerisinde şiddet eylemi barındıran bir davranışı seçme noktasında mekânın işlevselliğinin önemli olduğu ortaya çıkmıştır.

Diğer taraftan tutuklu ve mahkûm tarafından hedefin müsait ve erişilebilir olarak değerlendirilmesi durumunda suçun işlenme riski 3,33 kat artmaktadır. Ayrıca çevrede insan bulunmaması durumunda 3,33 kat suçun işlenme riski artmaktadır. Çevresel ve fiziksel açıdan önem taşıyan diğer faktörler dışında, insan faktörü ile hedefin müsait ve erişilebilir olmasının mala zarar verme suçu açısından önemli olduğunun tespit edilmesinin, suç kuramlarına katkı sağlayacağı düşünülmektedir. Bunun yanı sıra mala zarar verme suçu özelinde enter modelinde minör değişkenler çerçevesinde diğer modellere nazaran daha yüksek bir sınıflandırma yapılmıştır.

\section{Hırsızlık Suçuna Etki Eden Mekânsal Risklerin Belirlenmesi}

Hırsızlık suçunun işlendiği mekâna özgü değişkenlerin risk boyutlarının tespit edilmesi amacıyla yapılan lojistik regresyon analiziyle farklı modellerden tespit edilen sonuçlar aşağıda ifade edilmiştir. 
Tablo 12. Hırsızlık Suçu Verilerine Lojistik Regresyon Analizi (Enter) Uygulanması Sonucu Değişkenlerin Etki Düzeyleri

\begin{tabular}{|c|c|c|c|c|c|}
\hline Değişkenler & Katsayı & Wald İstatistiği & $\begin{array}{l}\text { Serbestlik } \\
\text { Derecesi } \\
\end{array}$ & $\begin{array}{l}\text { Belirleyici } \\
\text { Değer }\end{array}$ & $\begin{array}{l}\text { Risk } \\
\text { Katsayısı }\end{array}$ \\
\hline D1_1 & & 11,415 & 4 &, $022^{* *}$ & \\
\hline D1_1(1) & 1,228 & 1,191 & 1 & ,275 & 3,416 \\
\hline D1_1(2) & ,912 & 611 & 1 & , 434 & 2,488 \\
\hline D1_1(3) & $-2,535$ & 3,037 & 1 & 081 & ,079 \\
\hline D1_1(4) &,- 790 & 470 & 1 & ,493 & 454 \\
\hline D2_2 & & 9,466 & 4 &, $050^{* *}$ & \\
\hline D2_2(1) & $-3,695$ & 3,372 & 1 & ,066 & 025 \\
\hline D2_2(2) & $-6,157$ & 7,289 & 1 & , $007^{*}$ & ,002 \\
\hline D2_2(3) &,- 375 & ,096 & 1 & ,757 & 687 \\
\hline D2_2(4) &,- 767 & ,261 & 1 & 609 & 464 \\
\hline D3_3 & & 4,138 & 3 &, 247 & \\
\hline D3_3(1) &,- 813 & ,789 & 1 & ,375 & ,444 \\
\hline D3_3(2) & 1,106 & 830 & 1 & 362 & 3,022 \\
\hline D3_3(3) &,- 856 & 1,031 & 1 & 310 & 425 \\
\hline D9_1(1) &,- 480 & ,667 & 1 & ,414 & 619 \\
\hline D9_2(1) & $-1,491$ & 1,966 & 1 & ,161 & ,225 \\
\hline D9_3(1) & ,937 & 1,188 & 1 & ,276 & 2,554 \\
\hline D9_4(1) & $-1,463$ & 2,018 & 1 & ,155 & ,232 \\
\hline D9_5(1) & 1,870 & 8,625 & 1 &, $003^{*}$ & 6,491 \\
\hline D9_6(1) & 1,650 & 1,623 & 1 & ,203 & 5,207 \\
\hline D9_7(1) & ,174 & ,057 & 1 & 811 & 1,190 \\
\hline D10_1(1) & $-1,374$ & 3,638 & 1 & ,056 & ,253 \\
\hline D10_2(1) &,- 981 & 2,145 & 1 & ,143 & ,375 \\
\hline D10_3(1) & $-2,080$ & 5,598 & 1 & , $018^{*}$ & , 125 \\
\hline D10_4(1) & ,477 & ,159 & 1 & ,690 & 1,611 \\
\hline D10_5(1) & $-2,074$ & 8,639 & 1 & ,003* & , 126 \\
\hline Constant & 4,694 & 3,953 & 1 &, $047^{*}$ & 109,247 \\
\hline
\end{tabular}

$\left({ }^{*}, * * 0,05\right), D 1 \_1=$ Zarar Verilen Mekân (Trafikte Park Halinde/Seyreden Araç), D2_2= Mağdurla Yakınlık Derecesi(Tanımıyorum), D2_2(2)= Mağdurla Yakınlık Derecesi (Eşim), D9_5 (1)=Insan (Hayır), D10_3(1)= Suça Karşı Korumasız Olması(Hayır), D10_5 (1)=Hedefin Müsait ve Erişilebilir Olması(Hayır)

Hırsızlık suçundan dolayı ceza infaz kurumlarında bulunan tutuklu veya mahkûmlardan mekâna özgü alınan cevaplardan yukarıda belirtilen değişkenler esas alınarak \%82,9 oranında doğru yapılan lojistik regresyon analizi sonuçlarına göre çevrede insan bulunmaması, suçun oluşmasını 6,49 kat artırmaktadır. Hedefin suça karşı korumasız olması durumunda 8 kat, müsait ve erişilebilir olması durumunda ise 7,93 kat hırsızlık suçunun gerçekleşme ihtimali artmaktadır. Bununla beraber hırsızlık suçunu işleyen 
bireylerin mağdurların eşi olması durumunda tanımadığı bireylere göre, suçun işlenme riskini 50 kat azalmaktadır.

\section{Yă̆ma (Gasp) Suçuna Etki Eden Mekânsal Risklerin Belirlenmesi}

Yağma suçunun işlenme riskini artıran veya azaltan mekâna özgü özelliklerin tespit edilmesi amacıyla yapılan lojistik regresyon analiziyle ulaşılan farklı modellerden tespit edilen sonuçlar aşağıda ifade edilmiştir.

Tablo 13. Yă̆ma (Gasp) Suçu Verilerine Lojistik Regresyon Analizi (Enter) Uygulanması Sonucu Değişkenlerin Etki Düzeyleri

\begin{tabular}{|c|c|c|c|c|c|}
\hline Değişkenler & Katsayı & $\begin{array}{l}\text { Wald } \\
\text { İstatistiği }\end{array}$ & $\begin{array}{l}\text { Serbestlik } \\
\text { Derecesi }\end{array}$ & $\begin{array}{l}\text { Belirleyici } \\
\text { Değer }\end{array}$ & $\begin{array}{l}\text { Risk } \\
\text { Katsayıs1 }\end{array}$ \\
\hline D1_1 & & 14,618 & 4 &, $006^{* *}$ & \\
\hline D1_1(1) & $-2,032$ & 3,869 & 1 & ,049* & 131 \\
\hline D1_1(2) &,- 161 & ,027 & 1 & 869 & 852 \\
\hline D1_1(3) &,- 551 & ,167 & 1 & 683 & ,576 \\
\hline D1_1(4) & 828 & 688 & 1 & ,407 & 2,288 \\
\hline D2_2 & & 4,937 & 4 & 294 & \\
\hline D2_2(1) & 2,929 & 3,913 & 1 &, $048^{*}$ & 18,701 \\
\hline D2_2(2) & $-19,735$ &, 000 & 1 & ,999 &, 000 \\
\hline D2_2(3) &,- 558 & ,333 & 1 &, 564 &, 572 \\
\hline D2_2(4) & 1,395 & ,783 & 1 & ,376 & 4,037 \\
\hline D3_3 & & 5,315 & 3 & ,150 & \\
\hline D3_3(1) & ,082 & ,015 & 1 & ,901 & 1,086 \\
\hline D3_3(2) &,- 957 & 1,182 & 1 & ,277 & ,384 \\
\hline D3_3(3) & $-1,332$ & 3,222 & 1 & ,073 & 264 \\
\hline D9_1(1) & ,704 & 1,839 & 1 & , 175 & 2,022 \\
\hline D9_2(1) & ,343 & ,235 & 1 & 628 & 1,409 \\
\hline D9_3(1) & $-1,400$ & 3,477 & 1 & ,062 & 247 \\
\hline D9_4(1) &,- 429 & ,416 & 1 & ,519 & 651 \\
\hline D9_5(1) &,- 268 & ,239 & 1 & ,625 & ,765 \\
\hline D9_6(1) &,- 993 & ,974 & 1 & ,324 & 371 \\
\hline D9_7(1) &,- 399 & ,542 & 1 & ,462 & ,671 \\
\hline D10_1(1) & ,315 & ,376 & 1 & ,540 & 1,370 \\
\hline D10_2(1) &, 008 & ,000 & 1 & ,987 & 1,008 \\
\hline D10_3(1) & ,299 & 256 & 1 & 613 & 1,349 \\
\hline D10_4(1) & ,714 & ,742 & 1 & ,389 & 2,043 \\
\hline D10_5(1) & ,985 & 3,881 & 1 &, $049^{*}$ & 2,677 \\
\hline Constant & 1,022 & ,373 & 1 &, 541 & 2,779 \\
\hline
\end{tabular}

$\left({ }^{* * *}<0,05\right)$ D1=Zarar Verilen Mekân(Trafikte Park Halinde/Seyreden Araç), $\left.{ }^{* *}\right)$, D1(1)= Zarar Verilen Mekân (Mă̆durun Evi), D2_2(1)=_Akrabam, D10_5(1)=Hedefin Müsait ve Erişilebilir Olması(Hayır) 
Yağma suçunu işleyen tutuklu veya mahkûmlardan toplanan veriler vasitasıyla \%78,6 oranında doğru yapılan sınıflandırma sonuçlarına göre; mekânın majör faktör olarak suçun işlenmesinde anlamlı olduğu tespit edilmiştir. Öte yandan mağdurun evinin bulunduğu mekân, trafikte park halinde veya seyreden araçların bulunduğu mekâna göre suç işlenme riskini 7,63 kat azaltmaktadır. Mağdurların yüz yüze karşılaşarak suça maruz kaldıkları yağma suçunda mekânsal açıdan mağdurla bağ kurması sebebiyle suç işleyen bireylerin bu suç özelinde mağdurun yaşamını geçirdikleri yerlere dikkat ettikleri sonucuna ulaşılmıştır.

Bununla beraber yağma suçunu işleyen bireylerin mağdurların akrabası olması tanımadığı bireylere göre, suçun işlenme riskini 18,7 kat artmaktadır. Bu sonuç, bireyin yakın ilişki içerisinde bulunduğu diğer kişilerden saldırgan davranış beklememesi düşüncesiyle tezatlık oluşturmaktadır. Hedefin müsait ve erişilebilir olması durumunda ise suçun gerçekleşme ihtimali 2,67 kat azalmaktadır. Açıkçası bu sonuç, suçun hukuki niteliğiyle benzer bir sonuca ulaşmamızı sağlamıştır. Yağma suçunda malın mağdurdan cebir veya şiddet kullanarak zorla alınması durumu söz konusudur. Hedefin müsait ve erişilebilir olması durumunda suç işleyen bireyler doğrudan hedefe yönelerek, yağma suçu yerine, hirsızlık suçunu işlemektedirler.

\section{Sonuç}

Mala zarar verme, hırsızlık ve yağma suçlarının işlenmesini arttıran veya azaltan mekânsal risk faktörlerinin ele alındığ çalışmada adli sosyoloji bakış açısı kullanılmıştır. Adli sosyolojinin sahadan topladığı verilerin yargılama sürecinde görev alan soruşturma birimlerine katkı sağlayacağ1 düşünülmektedir.

Araştırmada mala zarar verme suçunun işlendiği mekânın kamuya açık alan olması durumunda mala zarar verme suçunun işlenme riskinin azaldığı sonucuna ulaşılmıştır. Bu anlamda mala zarar verme suçuna ilişkin olarak suç mekânında toplumsal denetimin olup olmaması suçun işlenme oranını etkilemektedir. Bunu destekleyecek şekilde suç işlendiği sırada çevrede başka insanların bulunmasının da söz konusu suçun işlenme riskini azalttığı tespit edilmiştir. Hedefin müsait ve erişilebilir 
olması durumunda ise mala zarar verme suçunun işlenme riski artmaktadir.

Çalışmada ele alınan hırsızlık suçuyla ilgili olarak çevrede başka insanların bulunması, suçun oluşmasını engelleyici bir faktör olarak tespit edilmiştir. Bunun yanı sıra hedefin suça karşı korunmasız olması, müsait ve erişilebilir olması durumunda ise suçun işlenme riski artmaktadır.

Yağma (gasp) suçuyla ilgili ulaşılan sonuçlar ise suçun kendine özgü özelliğine uygun olarak diğer suçlardan farklılık göstermektedir. Buna göre hedefin suçlu için müsait ve erişilebilir olmasının, suçun işlenmesi riskini azalttığı tespit edilmiştir. Ulaşılan bulgu, yağma suçunda mağdura cebir ve şiddet uygulanmasıyla açılanabilir. Hedefin müsait ve erişilebilir olması ise hırsızlık suçunu arttıran bir risk faktörüdür. Yağma suçuyla ilgili olarak ulaşılan diğer bir sonuç suç işleyen bireylerin, mağdurun yaşadığı mekânın özelliklerine (mekânın korunaklı olup olmaması gibi) dikkat etmeleridir. Bunun yanı sıra uygulanan anket sonuçlarında yağma suçu işleyen bireylerin, mağdurların akrabası olmasının suçun işlenmesi riskini arttırdığı ortaya çıkmıştır. Bu konudaki alan yazından farlı olarak bireyler arasındaki yakın ilişkilerin yağma suçunun işlenmesini engelleyen bir unsur olmadığı sonucuna ulaşılmıştır.

Mala zarar verme, hirsızlık ve yağma olmak üzere ele alınan her bir suça bağlı olarak mekânsal faktörlerin suçun işlenmesini arttırdığı veya azaldığı görülmektedir. Adli sosyoloji bakış açısıyla ortaya konan sonuçların adli birimler tarafından kullanılmasının söz konusu suç türleri özelinde suçun işlenmesini azaltacağı düşünülmektedir. 


\title{
EXTENDED ABSTRACT
}

\section{Analysis Of Spatial Risk Factors Related To Crime By Forensic Sociological Perspective}

\author{
Aykut Çalışkan - Tuğça Poyraz \\ Bayburt Police Department, Hacettepe University
}

Failure to undergo adequate control of the places where the crime has been committed may result in environments suitable for different offenses. In this context, understanding the concept of space not only as a physical phenomenon but also on the basis of crime is important to gain a forensic sociological perspective. The crime scene, on the one hand, refers to the environment in which the victim spends a certain period of time or meets their needs, while determining that the space is shaped by the social construction process is also important in terms of socially constructing the parameters of the problem. From the point of view of forensic sciences; on the other hand, it is also seen as a place on this place where the evidence that will contribute to the illumination of the event can be identified. The determination of the conditions describing the space is accepted as a prerequisite for illuminating the event.

In the researches, it was concluded that the lack of micro-level physical measures in the place and the lack of sociological factors such as collective consciousness, social control and social sensitivity had a significant effect on the committing of violent crimes (Brantingham et al., 1993, p.3-28, Anderson et al., 2012, p.699-756; Groff et al., 2009, p.61-86; Sampson et al., 2004, p.319342). Based on this narrative, the main reason of the study is to determine the factors that construct the space together with the physical elements and determine which variables are effective in committing the crime.

The statements of eyewitnesses who are present at the crime scene are considered as a source of evidence for the subsequent process, as well as the information they have provided, and the information provided can be clarified (Forst, 2004). The involving error possibility of the persons who are in the position of witnesses is critical in terms of establishing the causality and the relation event under which they have declared. 
In the investigations, the statements of the parties to the crime and the complainant in determining the clear identity of the suspect and providing them are largely shaped by the incident. For this purpose, determining the dimensions of neglect and defect in social and individual terms and analyzing the spatial characteristics of the environment in a comprehensive context are among the steps taken during the investigation process. The forensic sociology approach has emerged as a result of the approach from the social point of view as it investigates the characteristics of the actions defined as crime on a case-by-case basis, and provides data on the life styles of individuals involved in the judicial process (Füsun, 1997). The research carried out within this framework aims to determine spatial risk factors in terms of crime.

Hangout case of convicted individuals in the analysis process of sociological factors in particular to be represented in the best way the current sample of the provinces and the current state of social and demographic variables most provinces of the offenses in particular Turkey to be designed in a way that can predict differences regarding preferred. It was aimed that the individuals to be included in the sample consisted of male and female prisoners and the age distribution was between 18 and 65 years. For this purpose; in order to meet the specified conditions, the study was carried out in 3 provinces (Istanbul, Ankara and Izmir) with the highest number of crimes in respect of property damage, theft and robbery.

In the study, it has been aimed to apply totally 130 people by considering the number of samples ( 65 people) calculated by the data loss that may occur in the questionnaire forms; 120 males, 10 females (50 males for Istanbul, 5 females; 45 males for Izmir, 3 females and 25 males and 2 females for Ankara). More participation was made in voluntary and penal institutions on a voluntary basis, and the study was conducted with the participation of 154 prisoners or inmates.

In this study, spatial risk factors that increase or decrease the crimes of property damage, theft and looting are handled and the forensic sociology perspective is used. It is thought that the data collected by the forensic sociology from the field will contribute to the investigation units involved in the trial process.

In the study, it is concluded that the risk of the crime of damaging the property decreases if the committed damaging the property crime is open to 
the public. In this context, logistic regression analysis is used to specify the influence of spatial risk factors. In this sense, the presence of social control in the crime scene in relation to the crime of damaging the property affects the rate of committing the crime. In order to support this, it was found that the presence of other people in the vicinity at the time of the crime was reduced, thus reduced the risk of the crime. If the target is available and accessible, the risk of the crime of damaging the property increases.

The presence of other people in relation to the theft crime considered in the study was determined as a factor preventing the occurrence of the crime. In addition, if the target is vulnerable to crime, available and accessible, the risk of the crime increases.

The results of the pillage (extortion) crime differ from the other crimes in accordance with the peculiar feature of the crime. Accordingly, it has been found that the target's availability and accessibility to the offender reduces the risk of committing the offense. The finding can be explained by the use of algebra and violence to the victim of looting. The availability of the target is a risk factor that increases the crime of theft. Another result of the crime of looting is that individuals who commit crimes pay attention to the characteristics of the place where the victim lives (such as whether the place is sheltered). In addition, the results of the survey revealed that individuals who committed looting, relatives of the victims increased the risk of committing the crime. Apart from the literature on this subject, it has been concluded that close relationships between individuals are not a factor preventing the committing of looting.

It is seen that spatial factors increase or decrease the crime in relation to each crime that is dealt with, such as property damage, theft and looting. It is considered that the use of the results from the forensic sociology point of view by the judicial units will reduce the committing of the crime in the particular types of crime.

\section{Kaynakça / References}

Anderson, J. M., MacDonald, J. M., Bluthenthal, R. ve Ashwood, J.S. (2012). Reducing Crime by shaping the built environment with zoning: An Empirical study of Los Angeles. University of Pennsylvania Law Review. 
Bentham J. (1979). An introduction to the principles of morals and legislation, (J. Jacopy ed.), Classics of Criminology, içinde (s. 61-64).Oak Park, IL: Moore Publishing Company, Inc. ,

Brantingham, P. L. ve Brantingham, P. J. (1993). Nodes, paths and edges: Considerations on the complexity of crime and the physical environment, Journal of Environmental Psychology, 13(1), 3-28.

Clarke, R.V. ve Felson, M. (2004). Routine activity and rational choice theory advance in criminological theory. New Brunswick, NJ: Transaction Publishers.

Cohen, L.E. ve Felson, M. (1979). Social change and crime rate trends: A routine activity approach. American Sociological Review.

Forst B. (2004). Errors of justice: Nature, sources and remedies. New York: Cambridge University Press.

Füsun A. (1997). Suça etken olabilecek kişilik boyutlarnnın incelenmesi, Doktora Tezi. İstanbul Üniversitesi Adli Tıp Enstitüsü Sosyal Bilimler Anabilim Dalı.

Groff, E. D, Weisburd, N. ve Morris, A. (2009). Where the action is at places: Examining spatio-temporal patterns of juvenile crime at places using trajectory analysis and Gis. Putting Crime In Its Place, New York: Springer.

He, L., Páez, A. ve Liu, D. (2017). Built environment and violent crime: An environmental audit approach using Google Street View. Computers, Environment and Urban Systems, 66, 83-95. https://doi.org/10.1016/j.compen vurbsys.2017.08.001.

IBM Knowledge Center (t.y). Logistic regression variable selection methods, https://www.ibm.com/support/knowledgecenter/ko/SSLVMB_23.0.0/sp ss/regression/logistic_regression_methods.html adresinden erişilmiştir.

Macions, J. J. (2015). Sosyoloji. (Çev. Ed.: V. Akan), 13. Baskı, Ankara: Nobel Yayınları.

Malleson, N. ve Birkin, M. (2012). Analysis of crime patterns through the integration of anagent-based model and a population microsimulation, Computers, Environment and Urban Systems, 36(6), 551-561.

Petherick, W., Turvey, B. ve Ferguson, C. (2010). Forensic criminology. Netherlands: Elsevier, Amsterdam.

Sampson, R. ve Raudenbush, J.S.W. (2004). Seeing disorder: Neighborhood stigma and the social construction of broken windows. Social Psychology Quarterly, 67(4), 319-342.

Sherman, L. W., Gartin, P. R. ve Buerger, M. E. (1989). Hot spots of predatory crime: Routine activities and the criminology of place. Criminology, 27 (1), 30-31. 
TUIK (2019). Ceza infaz kurumuna giren hükümlü verilerine göre mala zarar verme suçunu işleyen bireyler. http://www.tuik.gov.tr/PreTablo.do?alt_id=1070 adresinden erişilmiştir.

Ünal B. (2007). Toplumbilim açısından yeni bir alan: Adli toplumbilim'e doğru (adli sosyoloji). Adli Psikiyatri Dergisi, 4, 37-41.

\section{Kaynakça Bilgisi / Citation Information}

Çalışkan, A. ve Poyraz, T. (2020). Suça ilişkin mekânsal risk faktörlerinin adli sosyolojik bakış açısıyla analizi. OPUS-Uluslararası Toplum Araştırmaları Dergisi, 15(21), 428-453. DOI: 10.26466/opus.648796 